\title{
Amycolatopsis granulosa sp. nov., Amycolatopsis ruanii sp. nov. and Amycolatopsis thermalba sp. nov., thermophilic actinomycetes isolated from arid soils
}

Correspondence Michael Goodfellow m.goodfellow@ncl.ac.uk

\author{
Tiago Domingues Zucchi, ${ }^{1,2}$ Geok Yuan Annie Tan, ${ }^{3}$ \\ Avinash Naga Venkata Bonda, ${ }^{1}$ Sarah Frank, ${ }^{1}$ \\ Jenileima Devi Kshetrimayum ${ }^{1}$ and Michael Goodfellow ${ }^{1}$
${ }^{1}$ School of Biology, University of Newcastle, Newcastle upon Tyne NE1 7RU, UK
${ }^{2}$ Departamento de Entomologia and Acarologia, ESALQ, Universidade de São Paulo, Piracicaba, Brazil
${ }^{3}$ Institute of Biological Sciences, Faculty of Science, University of Malaya, 50603 Kuala Lumpur, Malaysia

\begin{abstract}
The taxonomic positions of three thermophilic actinomycetes isolated from arid soil samples were established by using a polyphasic approach. The organisms had chemical and morphological features that were consistent with their classification in the genus Amycolatopsis. 16S rRNA gene sequence data supported the classification of the isolates in the genus Amycolatopsis and showed that they formed distinct branches in the Amycolatopsis methanolica subclade. DNADNA relatedness studies between the isolates and their phylogenetic neighbours showed that they belonged to distinct genomic species. The three isolates were readily distinguished from one another and from the type strains of species classified in the A. methanolica subclade based on a combination of phenotypic properties and by genomic fingerprinting. Consequently, it is proposed that the three isolates be classified in the genus Amycolatopsis as representatives of Amycolatopsis granulosa sp. nov. (type strain $\mathrm{GY} 307^{\top}=\mathrm{NCIMB} 14709^{\top}=\mathrm{NRRL} B-24844^{\top}$ ), Amycolatopsis ruanii sp. nov. (type strain NMG112 ${ }^{\top}=\mathrm{NCIMB} 14711^{\top}=\mathrm{NRRL} \mathrm{B}-24848^{\top}$ ) and Amycolatopsis thermalba sp. nov. (type strain $\mathrm{SF} 45^{\top}=\mathrm{NCIMB} 14705^{\top}=\mathrm{NRRL} B-24845^{\top}$ ).
\end{abstract}

The genus Amycolatopsis Lechevalier et al. (1986) can be readily distinguished from other genera classified in the family Pseudonocardiaceae by using genus-specific oligonucleotide primers based on $16 \mathrm{~S}$ rRNA gene sequences (Tan et al., 2006) and by a combination of chemotaxonomic features and morphological markers (Kim \& Goodfellow, 1999; Labeda et al., 2011). At the time of writing, the genus comprised 45 recognized species which fall into several multi- and single-membered subclades within the Amycolatopsis 16S rRNA gene tree (Albarracín et al., 2010; Tan \& Goodfellow, 2012). Amycolatopsis strains that grow at $50-55{ }^{\circ} \mathrm{C}$ belong to a well-delineated phyletic line, the Amycolatopsis methanolica subclade, which also encompasses Amycolatopsis eurytherma, A. thermoflava, A. thermophila, A. tucumanensis and A. viridis (Kim et al.,

The GenBank/EMBL/DDBJ accession numbers for the 16S rRNA gene sequences of strains $\mathrm{GY} 307^{\top}$, NMG $112^{\top}$ and $\mathrm{SF} 45^{\top}$ are AF466101, H0668524 and H0668525, respectively.

One supplementary figure and one supplementary table are available with the online version of this paper.
2002; Albarracín et al., 2010; Zucchi et al., 2012). Members of this subclade are of potential value in biotechnology, notably as vehicles for fermentative overproduction of aromatic amino acids (De Boer et al., 1990; Abou-Zeid et al., 1995) and as agents of bioremediation (Albarracín et al., 2008, 2010).

The present polyphasic taxonomic study was designed to establish the taxonomic status of three strains isolated from arid soil samples and found to have morphological properties similar to members of several genera classified in the family Pseudonocardiaceae, notably the genus Amycolatopsis. The organisms, isolates $\mathrm{GY} 307^{\mathrm{T}}$, NMG $112^{\mathrm{T}}$ and $\mathrm{SF} 45^{\mathrm{T}}$, were found to have properties resembling those of members of the A. methanolica subclade. It is proposed that these isolates be recognized as representatives of three novel species of the genus Amycolatopsis.

Strains $\mathrm{GY} 307^{\mathrm{T}}$ and $\mathrm{SF} 45^{\mathrm{T}}$ were isolated from SM2 and SM3 agar plates (Tan et al., 2006), respectively. Strain $S F 45^{\mathrm{T}}$ was obtained from an arid soil sample collected at Marla in Australia and strain $\mathrm{GY} 307^{\mathrm{T}}$ was from a composite Australian 
soil sample (Tan et al., 2006). Strain NMG112 ${ }^{\mathrm{T}}$ was isolated from a starch-casein agar plate (Küster \& Williams, 1964), which had been inoculated with a soil suspension of an arid soil sample and incubated at $28{ }^{\circ} \mathrm{C}$ for 21 days. The isolates were maintained on modified Bennett's agar plates (Jones, 1949) at room temperature and as suspensions of mycelial fragments in glycerol $(20 \%, \mathrm{v} / \mathrm{v})$ at $-20{ }^{\circ} \mathrm{C}$. Biomass for chemotaxonomic and molecular systematic studies was grown in shake flasks of glucose-yeast extract broth (Gordon \& Mihm, 1962) for 7 days at $28{ }^{\circ} \mathrm{C}$, harvested by centrifugation and washed twice in distilled water; biomass for chemotaxonomic studies was freeze-dried.

Extraction of genomic DNA, PCR amplification and sequencing of $16 \mathrm{~S}$ rRNA genes of the novel isolates were performed as described by Kim et al. (1996). The almostcomplete 16S rRNA gene sequences (1392-1476 nt) were aligned against corresponding sequences of the type strains of Amycolatopsis species retrieved from the EzTaxon database (Chun et al., 2007) by using MEGA4 software (Tamura et al., 2007). Phylogenetic trees were inferred by using the maximum-likelihood (Felsenstein, 1981), maximum-parsimony (Fitch, 1971) and neighbour-joining (Saitou \& Nei, 1987) tree-making algorithms drawn from the MEGA4 and PHYML packages (Guindon \& Gascuel, 2003; Tamura et al., 2007); an evolutionary distance matrix was generated for the neighbour-joining algorithm by using the Jukes \& Cantor (1969) distance model. The topologies of the evolutionary trees were evaluated by bootstrap analysis (Felsenstein, 1985) of the neighbour-joining method based on 1000 replicates by using the MEGA4 software package. The root position of the neighbour-joining tree was inferred by using Prauserella rugosa DSM $43194^{\mathrm{T}}$ (GenBank accession no. AF051342) and Saccharomonospora viridis NCIB $9602^{\mathrm{T}}$ (GenBank accession no. Z38007) as outgroups.

Phylogenetic analysis showed that each of the novel isolates formed a distinct phyletic line within the A. methanolica subclade (Fig. 1). They shared 99.0-99.2\% 16S rRNA gene similarity, which corresponded to 14-23 nt differences at 1390-1415 locations. The relationship between strain GY3 $37^{\mathrm{T}}$ and its closest neighbour, the type strain of $A$. viridis, was supported by the maximum-parsimony algorithm and a $98 \%$ bootstrap value; the two organisms shared $99.0 \% 16 \mathrm{~S}$ rRNA gene sequence similarity, a value corresponding to $14 \mathrm{nt}$ differences at 1387 sites. The loose relationship between strain $\mathrm{NMG}_{1} 12^{\mathrm{T}}$ and the type strains of A. methanolica and A. thermoflava was not supported by the other tree-making algorithms or by a high bootstrap value. Indeed, this isolate was recovered at the periphery of the A. methanolica subclade in the analyses based on the maximum-likelihood and maximum-parsimony algorithms. Strain NMG112 ${ }^{\mathrm{T}}$ was related most closely to the type strains of $A$. methanolica and A. thermoflava, with which it shared 98.8 and $98.9 \% 16 \mathrm{~S}$ rRNA gene sequence similarity, respectively, values equivalent to 17 and $16 \mathrm{nt}$ differences. In contrast, strain SF45 ${ }^{\mathrm{T}}$ and the type strains of A. eurytherma and A. tucumanensis formed a phyletic branch that was supported by all of the tree-making algorithms but not by a high bootstrap value. Strain $\mathrm{SF} 45^{\mathrm{T}}$ was related most closely to the type strain of A. eurytherma, with which it shared $99.2 \% 16 \mathrm{~S}$ rRNA gene sequence similarity, a value which corresponded to $11 \mathrm{nt}$ differences at 1389 sites.

DNA-DNA hybridization experiments were carried out between strain $\mathrm{GY} 307^{\mathrm{T}}$ and $A$. viridis $\mathrm{GY} 115^{\mathrm{T}}$, strain $\mathrm{NMG} 12^{\mathrm{T}}$ and $A$. methanolica IMSNU $20055^{\mathrm{T}}$, and strain

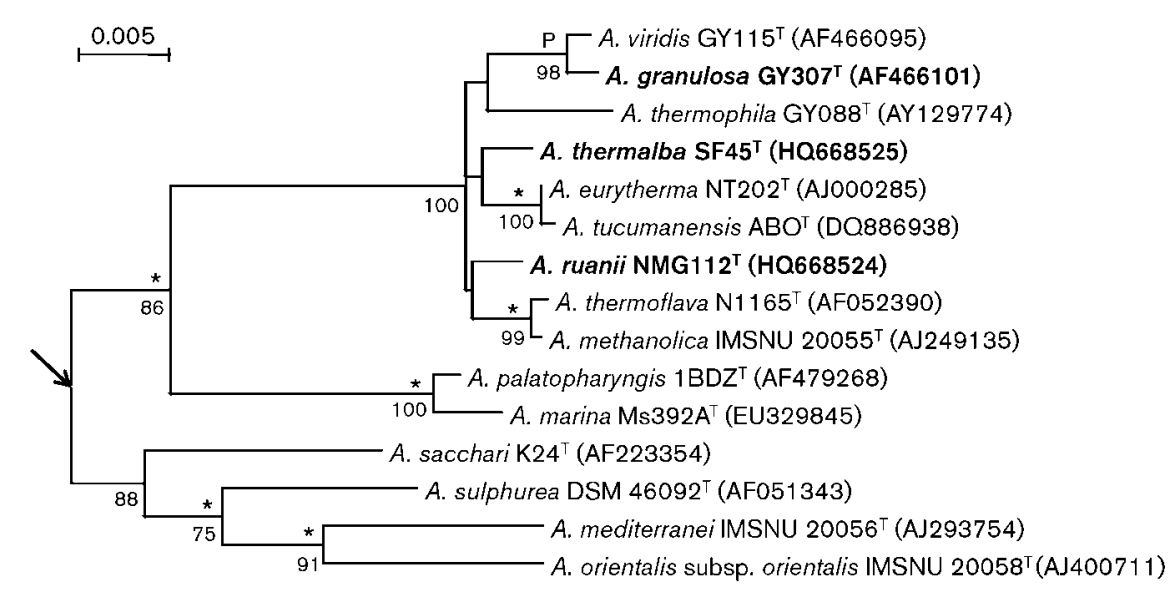

Fig. 1. Neighbour-joining tree based on almost-complete 16S rRNA gene sequences showing relationships between isolates GY $307^{\top}, N M G 112^{\top}$ and SF $45^{\top}$ and the type strains of species classified in the Amycolatopsis methanolica subclade. Asterisks indicate branches of the tree that were also found with the maximum-likelihood and maximum-parsimony tree-making algorithms; $\mathrm{P}$ indicates branches that were recovered with the maximum-parsimony method. Numbers at nodes indicate levels of bootstrap support (\%) based on a neighbour-joining analysis of 1000 resampled datasets; only values $>50 \%$ are given. The arrow indicates the inferred root position by using Prauserella rugosa DSM $43194^{\top}$ (AF051342) and Saccharomonospora viridis NCIB $9602^{\top}$ (Z38007) as outgroups. Bar, 0.005 substitutions per nucleotide position. 
$\mathrm{SF} 45^{\mathrm{T}}$ and A. eurytherma NT202 ${ }^{\mathrm{T}}$, even though these pairs of strains showed lower 16S rRNA gene sequence similarities than between the type strains of species classified in the $A$. methanolica subclade (Chun et al., 1999; Albarracín et al., 2010). Levels of DNA-DNA relatedness between the three pairs of strains were determined in triplicate by using the nitrocellulose membrane-filter hybridization procedure described by Seldin \& Dubnau (1985). The DNA probes were labelled by using the non-radioactive digoxigenin High Prime System (Roche), hybridized DNA was visualized by using digoxigenin luminescent detection kits (Roche) and DNA-DNA relatedness was quantified by using a densitometer (Bio-Rad). The resultant mean $( \pm \mathrm{SD})$ levels of DNADNA relatedness were $50.0 \pm 5.0 \%$ between strain GY307 ${ }^{\mathrm{T}}$ and $A$. viridis $\mathrm{GY}_{115^{\mathrm{T}}}, 42.2 \pm 2.7 \%$ between strain $\mathrm{NMG} 112^{\mathrm{T}}$ and A. methanolica IMSNU $20055^{\mathrm{T}}$, and $39.5 \pm 3.4 \%$ between strain $\mathrm{SF} 45^{\mathrm{T}}$ and A. eurytherma $\mathrm{NT} 202^{\mathrm{T}}$; these values are well below the $70 \%$ cut-off point recommended for the assignment of strains to the same genomic species (Wayne et al., 1987).

Repetitive DNA fingerprinting was performed in duplicate on the three novel isolates and the type strains of species classified in the A. methanolica subclade by using the BOX A1R primer (5'-CTACGGCAAGGCGACGCTGACG-3'), following the protocol described by Versalovic et al. (1994). The resultant fingerprints were analysed by using Bionumerics version 2 software (Applied Maths). Each fingerprint was normalized by using a standard molecular marker and the bands were defined prior to cluster analysis. A similarity matrix was calculated with the pairwise Pearson product-moment correlation coefficient (Pearson, 1926) followed by construction of a dendrogram via the unweighted-pair-group method with arithmetic averages algorithm (UPGMA; Sokal \& Michener, 1958). The three novel strains formed single-membered clusters at the $92 \%$ cut-off point in each of the duplicate sets (Fig. 2).

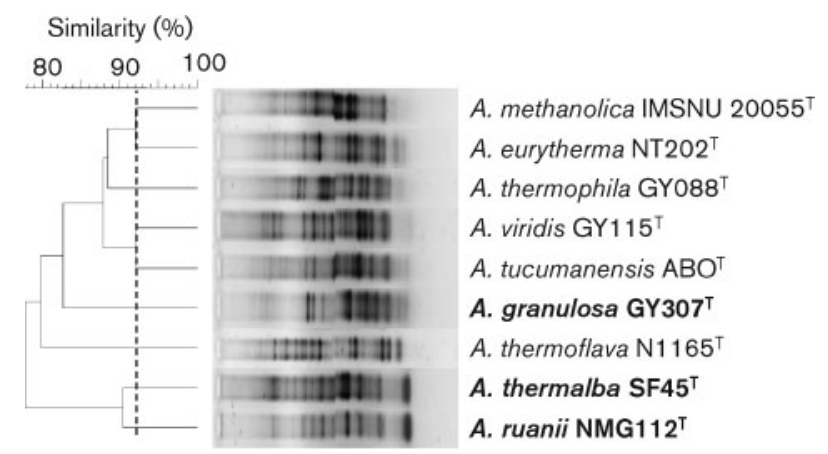

Fig. 2. Dendrogram showing clustering of $B O X A 1 R$ fingerprints of isolates $\mathrm{GY} 307^{\top}, \mathrm{NMG} 112^{\top}$ and $\mathrm{SF} 45^{\top}$ and the type strains of species classified in the $A$. methanolica 16S rRNA gene subclade (Pearson correlation; 1-100\%). The dashed line indicates the $92 \%$ cut-off value.
Standard procedures were used to determine the isomers of diaminopimelic acid (Staneck \& Roberts, 1974), the acyl type of murein (Uchida et al., 1999), sugars (Schaal, 1985), menaquinones and polar lipids (Minnikin et al., 1984), by using the type strains of A. methanolica, A. tucumanensis and A. viridis as controls. All of the isolates contained mesodiaminopimelic acid, arabinose and galactose in wholeorganism hydrolysates (wall chemotype IV after Lechevalier \& Lechevalier, 1970), together with $\mathrm{N}$-acetylated muramic acid, and major amounts of diphosphatidylglycerol, phosphatidylethanolamine, phosphatidylmethylethanolamine, phosphatidylglycerol and phosphatidylinositol (Fig. S1 available in IJSEM Online; phospholipid pattern II sensu Lechevalier et al., 1977). The predominant isoprenologue of strains $\mathrm{GY} 307^{\mathrm{T}}$ and $\mathrm{NMG} 112^{\mathrm{T}}$ was tetra-hydrogenated menaquinone with nine isoprene units $\left[\mathrm{MK}-9\left(\mathrm{H}_{4}\right)\right]$ and that of isolate $\mathrm{SF} 45^{\mathrm{T}}$ was MK- $9\left(\mathrm{H}_{2}\right)$. These results are in line with those of previous studies, as representatives of Amycolatopsis species contain di-, tetra-, hexa- or octahydrogenated menaquinones with nine isoprene units as predominant components (Lechevalier et al., 1986; Yassin et al., 1991; Huang et al., 2004; Wink et al., 2003; Albarracín et al., 2010). In contrast, Amycolatopsis halophila and Amycolatopsis nigrescens strains contain $\mathrm{MK}-8\left(\mathrm{H}_{4}\right)$ and MK-11 $\left(\mathrm{H}_{4}\right)$ as respective predominant isoprenologues (Groth et al., 2007; Tang et al., 2010). Furthermore, the type strain of Amycolatopsis decaplanina is reported to have a mixture of tetra-hydrogenated menaquinones with eight and nine isoprene units (Wink et al., 2004). It is apparent that the predominant menaquinones vary considerably in the genus (Tan \& Goodfellow, 2012), although some of this variation may be attributed to the stage of the growth cycle from which biomass is taken (Yassin et al., 1991). Consequently, all of these chemical properties support the assignment of the isolates to the genus Amycolatopsis (Tan \& Goodfellow, 2012).

Fatty acids extracted from the isolates and from the type strains of species classified in the A. methanolica subclade were methylated then analysed by using the standard Sherlock Microbial Identification (MIDI) system, version 5 (MIDI, 1999; Sasser, 1990). All of the strains contained iso- $\mathrm{C}_{16: 0}$ as the predominant fatty acid $(29.5-48.7 \%$ of the total fatty acids) and major proportions of $\mathrm{C}_{16: 0}$ (6.5$13.2 \%)$ and anteiso- $\mathrm{C}_{17: 0}(6.5-18.3)$, results that are in line with those from previous studies (De Boer et al., 1990; Chun et al., 1999; Albarracín et al., 2010). It can be seen from the fatty acid profiles shown in Table S1 that some of the minor components are discontinuously distributed and that, apart from the type strain of A. viridis, all of the organisms contain major proportions of iso- $\mathrm{C}_{16: 0} 2-\mathrm{OH}$ $(7.3-16.4 \%)$.

The novel isolates and the type strains of species classified in the A. methanolica subclade were examined for phenotypic properties known to be of value in Amycolatopsis systematics (De Boer et al., 1990; Kim et al., 2002; Tan \& Goodfellow, 2012). Additional biochemical features were obtained by using API ZYM test strips (bioMérieux), 
following the manufacturer's protocol. The isolates were readily distinguished from one another and from the type strains of their nearest neighbours by using a combination of phenotypic properties (Table 1). Isolate $\mathrm{GY} 307^{\mathrm{T}}$, unlike the type strain of $A$. viridis, produced acid from dextrin, mesoerythritol, methyl $\alpha$-D-glucoside, raffinose, D-ribose, sucrose and D-xylose, and produced trypsin, but did not grow at $10{ }^{\circ} \mathrm{C}$. Similarly, isolate $\mathrm{NMG} 12^{\mathrm{T}}$ could be distinguished from the type strains of $A$. methanolica and A. thermoflava by its ability to produce acid from dextrin, mesoerythritol, D-galactose, myo-inositol, maltose, D-mannitol and methyl $\alpha$-D-glucoside and by its inability to produce naphthol-AS-BI-phosphohydrolase. In turn, isolate SF $45^{\mathrm{T}}$, unlike the type strain of A. eurytherma, formed acid from maltose, methyl $\alpha$-D-glucoside, raffinose and D-ribose, produced $\beta$-glucosidase, did not degrade hypoxanthine

Table 1. Characteristics differentiating isolates $\mathrm{GY} 307^{\top}, \mathrm{NMG1} 12^{\top}$ and $\mathrm{SF} 45^{\top}$ from one another and from their closest phylogenetic relatives in the genus Amycolatopsis

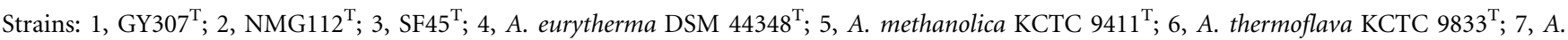
thermophila NRRL B-24836 ${ }^{\mathrm{T}}$; 8, A. tucumanensis DSM $45259^{\mathrm{T}} ; 9$, A. viridis NRRL B- $24837^{\mathrm{T}}$. All data are from this study.

\begin{tabular}{|c|c|c|c|c|c|c|c|c|c|}
\hline Characteristic & 1 & 2 & 3 & 4 & 5 & 6 & 7 & 8 & 9 \\
\hline \multicolumn{10}{|l|}{ Properties on oatmeal agar } \\
\hline Formation/colour of aerial hyphae & White & White & White & White & White & White & - & - & White \\
\hline Colour of substrate mycelium & Yellow-green & Yellow & Yellow & Yellow & Yellow & Yellow & Yellow-brown & Yellow & Yellow-green \\
\hline Production of soluble pigment & - & - & - & - & - & + & - & - & - \\
\hline \multicolumn{10}{|l|}{ Acid production from: } \\
\hline (+)-L-Arabinose & + & + & + & + & + & + & - & + & + \\
\hline Dextrin & + & + & + & + & - & - & - & - & - \\
\hline meso-Erythritol & + & + & + & + & - & + & - & + & - \\
\hline (+)-D-Galactose & + & + & + & + & + & + & - & + & + \\
\hline myo-Inositol & - & + & + & + & - & - & - & - & - \\
\hline (+)-D-Lactose & + & + & + & + & + & + & - & + & + \\
\hline Maltose & - & + & + & - & - & - & - & - & - \\
\hline$(-)$-D-Mannitol & - & + & + & + & - & + & - & + & - \\
\hline Melibiose & - & - & - & - & - & + & - & - & - \\
\hline Methyl $\alpha$-D-glucoside & + & + & + & - & - & + & - & + & - \\
\hline Raffinose & + & + & + & - & + & + & - & + & - \\
\hline (+)-D-Ribose & + & + & + & - & + & + & - & - & - \\
\hline (-)-D-Sorbitol & - & + & + & + & + & + & - & + & - \\
\hline (-)-D-Sucrose & + & + & - & - & + & - & - & + & - \\
\hline Trehalose & + & - & + & + & + & + & - & - & + \\
\hline (+)-D-Xylose & + & + & + & + & + & + & - & + & - \\
\hline \multicolumn{10}{|l|}{ Degradation of: } \\
\hline Allantoin & - & - & + & + & - & + & - & - & - \\
\hline Hypoxanthine & + & + & - & + & + & + & - & - & + \\
\hline Uric acid & + & + & - & - & + & + & - & + & + \\
\hline Xylan & + & + & - & - & - & - & + & + & + \\
\hline \multicolumn{10}{|l|}{ API ZYM tests } \\
\hline$N$-Acetyl- $\beta$-glucosaminidase & - & + & - & + & + & + & + & - & - \\
\hline Acid phosphatase & + & + & - & + & + & + & + & + & + \\
\hline Alkaline phosphatase & + & + & + & + & + & + & - & - & + \\
\hline Cystine arylamidase & + & - & - & + & + & + & - & - & + \\
\hline Esterase lipase (C8) & + & + & + & + & + & - & + & + & + \\
\hline$\beta$-Galactosidase & + & - & - & - & - & - & - & - & + \\
\hline$\beta$-Glucosidase & - & - & + & - & + & - & - & + & - \\
\hline$\beta$-Glucuronidase & + & - & - & - & - & - & - & - & + \\
\hline Leucine arylamidase & + & + & + & + & + & + & - & + & + \\
\hline Lipase (C14) & + & - & - & + & + & - & - & - & + \\
\hline Naphthol-AS-BI-phosphohydrolase & + & - & + & + & + & + & + & - & + \\
\hline Trypsin & + & - & - & + & + & + & - & - & - \\
\hline Valine arylamidase & + & - & - & + & + & + & - & - & + \\
\hline Growth at $10{ }^{\circ} \mathrm{C}$ & - & - & - & - & + & - & + & - & + \\
\hline
\end{tabular}


and did not produce $N$-acetyl- $\beta$-glucosaminidase, acid phosphatase, cystine arylamidase, lipase (C4), trypsin or valine arylamidase.

The genotypic and phenotypic data presented here show that the three isolates can be distinguished from one another and from the type strains of species classified in the $A$. methanolica 16S rRNA gene subclade. We therefore suggest that strains $\mathrm{GY} 307^{\mathrm{T}}, \mathrm{NMG} 12^{\mathrm{T}}$ and $\mathrm{SF} 45^{\mathrm{T}}$ represent three novel species of the genus Amycolatopsis, for which the names Amycolatopsis granulosa sp. nov., Amycolatopsis ruanii sp. nov. and Amycolatopsis thermalba sp. nov., respectively, are proposed.

\section{Description of Amycolatopsis granulosa sp. nov.}

Amycolatopsis granulosa (gra.nu.lo'sa. L. n. granulum a small grain; L. fem. suff. -osa suffix meaning full of; N.L. fem. adj. granulosa granular).

Aerobic, Gram-positive, non-acid-alcohol-fast, non-motile, catalase-positive actinomycete. Forms abundant, white aerial hyphae and a yellow-green substrate mycelium that fragments into cylindrical elements $(0.4-0.5 \times 1.0-1.2 \mu \mathrm{m})$ with a granular ornamentation on modified Bennett's agar supplemented with mannitol and soybean flour; diffusible pigments are not formed on this medium. Grows at 20 $50{ }^{\circ} \mathrm{C}$ and $\mathrm{pH} 5.0-7.0$ but not in the presence of $\mathrm{NaCl}(5 \%$, $\mathrm{w} / \mathrm{v})$. Acid is produced from $\mathrm{D}$-fructose, $\mathrm{D}$-mannose and melezitose, but not from D-arabitol, dulcitol, glycogen or xylitol. Chitin, gelatin and starch are degraded, but not cellulose, guanine, tyrosine or xanthine. Does not produce chymotrypsin, $\alpha$-galactosidase, $\alpha$-glucosidase, $\alpha$-mannosidase or $\alpha$-fucosidase (API ZYM tests). Additional phenotypic test results are given in the main text and in Table 1. Chemotaxonomic properties are typical of the genus.

The type strain, GY307 ${ }^{\mathrm{T}} \quad\left(=\mathrm{NCIMB} \quad 14709^{\mathrm{T}}=\mathrm{NRRL}\right.$ B-24844 $4^{\mathrm{T}}$ ), was isolated from an arid soil sample collected from Marla, Australia. The species description is based on a single strain and hence serves as the description of the type strain.

\section{Description of Amycolatopsis ruanii sp. nov.}

Amycolatopsis ruanii (ru.a'ni.i. N.L. gen. masc. n. ruanii of Ruan, named after Jisheng Ruan in recognition of his many contributions to the systematics of actinomycetes).

Aerobic, Gram-positive, non-acid-alcohol-fast, nonmotile, catalase-positive actinomycete. Forms abundant white aerial hyphae and an extensively branched yellow substrate mycelium that fragments into granular ornamented cylindrical elements $(0.3-0.5 \times 1.2-1.7 \mu \mathrm{m})$ on modified Bennett's agar supplemented with mannitol and soybean flour; diffusible pigments are not formed on this medium. Grows at $20-50{ }^{\circ} \mathrm{C}$, at $\mathrm{pH} 4.0-10.0$ and in the presence of $\mathrm{NaCl}(7.0 \%, \mathrm{w} / \mathrm{v})$. Acid is produced from Dfructose, glycogen, D-mannose, melezitose and xylitol, but not from D-arabitol or dulcitol. Degrades chitin, gelatin and starch, but not cellulose, guanine, tyrosine or xanthine. Does not produce chymotrypsin, $\alpha$-galactosidase, $\alpha$-glucosidase, $\alpha$-mannosidase or $\alpha$-fucosidase (API ZYM tests). Additional phenotypic test results are given in the main text and in Table 1. Chemotaxonomic properties are typical of the genus.

The type strain, NMG112 ${ }^{\mathrm{T}}\left(=\mathrm{NCIMB} 14711^{\mathrm{T}}=\mathrm{NRRL}\right.$ $\left.\mathrm{B}-24848^{\mathrm{T}}\right)$, was isolated from an arid soil sample. The species description is based on a single strain and hence serves as the description of the type strain.

\section{Description of Amycolatopsis thermalba sp. nov.}

Amycolatopsis thermalba (therm.al'ba. Gr. n. thermê heat; L. fem. adj. alba white; N.L. fem. adj. thermalba thermophilic and white).

Aerobic, Gram-positive, non-acid-alcohol-fast, non-motile, catalase-positive actinomycete. Forms an extensively branched substrate mycelium that fragments into smooth-walled, cylindrical elements $(0.3-0.4 \times 1.5-1.8 \mu \mathrm{m})$. Abundant, white sterile aerial hyphae, a yellow substrate mycelium and a medium olive brown diffusible pigment are produced on modified Bennett's agar supplemented with mannitol and soybean flour. Grows at $20-50{ }^{\circ} \mathrm{C}$, at $\mathrm{pH} 4.0-10.0$ and in the presence of $\mathrm{NaCl}(7.0 \%, \mathrm{w} / \mathrm{v})$. Acid is produced from D-fructose, glycogen, D-mannose, melezitose and xylitol, but not from D-arabitol or dulcitol. Gelatin and starch are degraded, but not chitin, cellulose, guanine, tyrosine or xanthine. Does not produce chymotrypsin, $\alpha$-fucosidase, $\alpha$ galactosidase, $\alpha$-glucosidase or $\alpha$-mannosidase (API ZYM tests). Additional phenotypic test results are given in the main text and in Table 1. Chemotaxonomic properties are typical of the genus.

The type strain, SF $45^{\mathrm{T}}\left(=\mathrm{NCIMB} 14705^{\mathrm{T}}=\right.$ NRRL B-24845 $\left.{ }^{\mathrm{T}}\right)$, was isolated from an arid soil sample collected at Marla, Australia. The species description is based on a single strain and hence serves as the description of the type strain.

\section{Acknowledgements}

T.D.Z. is indebted to the Conselho Nacional de Desenvolvimento Científico e Tecnológico for a fellowship to study in the UK (grant 201066/2009-2). We are also indebted to Professor Roberto Zucchi (ESALQ/USP, Brazil) and Professor Jean Euzéby (Ecolé Nationale Vétérinaire de Toulouse, France) for help in naming the novel species and to Soon-Wo Kwon and Hang-Yeon Weon for carrying out the DNA-DNA hybridization and fatty acid analyses.

\section{References}

Abou-Zeid, A., Euverink, G. J. W., Hessels, G. I., Jensen, R. A. \& Dijkhuizen, L. (1995). Biosynthesis of L-phenylalanine and L-tyrosine in the actinomycete Amycolatopsis methanolica. Appl Environ Microbiol 61, 1298-1302.

Albarracín, V. H., Winik, B., Kothe, E., Amoroso, M. J. \& Abate, C. M. (2008). Copper bioaccumulation by the actinobacterium Amycolatopsis sp. AB0. J Basic Microbiol 48, 323-330. 
Albarracin, V. H., Alonso-Vega, P., Trujillo, M. E., Amoroso, M. J. \& Abate, C. M. (2010). Amycolatopsis tucumanensis sp. nov., a copperresistant actinobacterium isolated from polluted sediments. Int J Syst Evol Microbiol 60, 397-401.

Chun, J., Kim, S. B., Oh, Y. K., Seong, C.-N., Lee, D.-H., Bae, K. S., Lee, K.-J., Kang, S.-O., Hah, Y. C. \& Goodfellow, M. (1999). Amycolatopsis thermoflava sp. nov., a novel soil actinomycete from Hainan Island, China. Int J Syst Bacteriol 49, 1369-1373.

Chun, J., Lee, J.-H., Jung, Y., Kim, M., Kim, S., Kim, B. K. \& Lim, Y. W. (2007). EzTaxon: a web-based tool for the identification of prokaryotes based on 16S ribosomal RNA gene sequences. Int J Syst Evol Microbiol 57, 2259-2261.

De Boer, L., Dijkhuizen, L., Grobben, G., Goodfellow, M., Stackebrandt, E., Parlett, J. H., Whitehead, D. \& Witt, D. (1990). Amycolatopsis methanolica sp. nov., a facultatively methylotrophic actinomycete. Int J Syst Bacteriol 40, 194-204.

Felsenstein, J. (1981). Evolutionary trees from DNA sequences: a maximum likelihood approach. J Mol Evol 17, 368-376.

Felsenstein, J. (1985). Confidence limits on phylogenies: an approach using the bootstrap. Evolution 39, 783-791.

Fitch, W. M. (1971). Towards defining the course of evolution: minimum change for a specific tree topology. Syst Zool 20, 406416.

Gordon, R. E. \& Mihm, J. M. (1962). Identification of Nocardia caviae (Erikson) nov. comb. Ann N Y Acad Sci 98, 628-636.

Groth, I., Tan, G. Y. A., González, J. M., Laiz, L., Carlsohn, M. R., Schütze, B., Wink, J. \& Goodfellow, M. (2007). Amycolatopsis nigrescens sp. nov., an actinomycete isolated from a Roman catacomb. Int J Syst Evol Microbiol 57, 513-519.

Guindon, S. \& Gascuel, O. (2003). A simple, fast, and accurate algorithm to estimate large phylogenies by maximum likelihood. Syst Biol 52, 696-704.

Huang, Y., Paściak, M., Liu, Z., Xie, Q. \& Gamian, A. (2004). Amycolatopsis palatopharyngis sp. nov., a potentially pathogenic actinomycete isolated from a human clinical source. Int J Syst Evol Microbiol 54, 359-363.

Jones, K. L. (1949). Fresh isolates of actinomycetes in which the presence of sporogenous aerial mycelia is a fluctuating characteristic. J Bacteriol 57, 141-145.

Jukes, T. H. \& Cantor, C. R. (1969). Evolution of protein molecules. In Mammalian Protein Metabolism, vol. 3, pp. 21-132. Edited by H. N. Munro. New York: Academic Press.

Kim, S. B. \& Goodfellow, M. (1999). Reclassification of Amycolatopsis rugosa Lechevalier et al. 1986 as Prauserella rugosa gen. nov., comb. nov. Int J Syst Bacteriol 49, 507-512.

Kim, D., Chun, J., Sahin, N., Hah, Y. C. \& Goodfellow, M. (1996). Analysis of thermophilic clades within the genus Streptomyces by $16 \mathrm{~S}$ rRNA ribosomal DNA sequence comparisons. Int J Syst Bacteriol 46, 581-587.

Kim, B., Sahin, N., Tan, G. Y. A., Zakrzewska-Czerwinska, J. \& Goodfellow, M. (2002). Amycolatopsis eurytherma sp. nov., a thermophilic actinomycete isolated from soil. Int J Syst Evol Microbiol 52, 889-894.

Küster, E. \& Williams, S. T. (1964). Selection of media for isolation of streptomycetes. Nature 202, 928-929.

Labeda, D. P., Goodfellow, M., Chun, J., Zhi, X.-Y. \& Li, W.-J. (2011). Reassessment of the systematics of the suborder Pseudonocardineae: transfer of the genera within the family Actinosynnemataceae Labeda and Kroppenstedt 2000 emend. Zhi et al. 2009 into an emended family Pseudonocardiaceae Embley et al. 1989 emend. Zhi et al. 2009. Int J Syst Evol Microbiol 61, 1259-1264.
Lechevalier, M. P. \& Lechevalier, H. (1970). Chemical composition as a criterion in the classification of aerobic actinomycetes. Int J Syst Bacteriol 20, 435-443.

Lechevalier, M. P., De Biévre, C. \& Lechevalier, H. (1977). Chemotaxonomy of aerobic actinomycetes: phospholipid composition. Biochem Syst Ecol 5, 249-260.

Lechevalier, M. P., Prauser, H., Labeda, D. P. \& Ruan, J.-S. (1986). Two new genera of nocardioform actinomycetes: Amycolata gen. nov. and Amycolatopsis gen. nov. Int J Syst Bacteriol 36, 29-37.

MIDI (1999). Sherlock Microbial Identification System, Operating Manual, version 30. Newark, DE: MIDI Inc.

Minnikin, D. E., O’Donnell, A. G., Goodfellow, M., Alderson, G., Athalye, M., Schaal, A. \& Parlett, J. H. (1984). An integrated procedure for the extraction of bacterial isoprenoid quinones and polar lipids. J Microbiol Methods 2, 233-241.

Pearson, K. (1926). On the coefficient of racial likeness. Biometrika 18, 105-117.

Saitou, N. \& Nei, M. (1987). The neighbor-joining method: a new method for reconstructing phylogenetic trees. Mol Biol Evol 4, 406-425.

Sasser, M. (1990). Identification of bacteria by gas chromatography of cellular fatty acids, MIDI Technical Note 101. Newark, DE: MIDI Inc.

Schaal, K. P. (1985). Identification of clinically significant actinomycetes and related bacteria using chemical techniques. In Chemical Methods in Bacterial Systematics, pp. 359-381. Edited by M. Goodfellow $\&$ D. E. Minnikin. London: Academic Press.

Seldin, L. \& Dubnau, D. (1985). Deoxyribonucleic acid homology amongst Bacillus polymxya, Bacillus macerans, Bacillus azotofixans, and other nitrogen-fixing Bacillus strains. Int J Syst Bacteriol 35, 151-154.

Sokal, R. R. \& Michener, C. D. (1958). A statistical method for evaluating systematic relationships. Univ Kansas Sci Bull 38, 14091438.

Staneck, J. L. \& Roberts, G. D. (1974). Simplified approach to identification of aerobic actinomycetes by thin-layer chromatography. Appl Microbiol 28, 226-231.

Tamura, K., Dudley, J., Nei, M. \& Kumar, S. (2007). MEGA4: molecular evolutionary genetics analysis (MEGA) software version 4.0. Mol Biol Evol 24, 1596-1599.

Tan, G. Y. A. \& Goodfellow, M. (2012). Genus IV. Amycolatopsis (Lechevalier, Prauser, Labeda and Ruan 1986) Lee 2009, $1403^{\mathrm{VP}}$. In Bergey's Manual of Systematic Bacteriology, The Actinobacteria, 2nd edn, vol. 5. Edited by M. Goodfellow, P. Kämpfer, H.-J. Busse, M. E. Trujillo, K. Suzuki, W. Ludwig \& W. B. Whitman. New York: Springer (in press).

Tan, G. Y. A., Ward, A. C. \& Goodfellow, M. (2006). Exploration of Amycolatopsis diversity in soil using genus-specific primers and novel selective media. Syst Appl Microbiol 29, 557-569.

Tang, S.-K., Wang, Y., Guan, T.-W., Lee, J.-C., Kim, C.-J. \& Li, W.-J. (2010). Amycolatopsis halophila sp. nov., a halophilic actinomycete isolated from a salt lake. Int J Syst Evol Microbiol 60, 1073-1078.

Uchida, K., Kudo, T., Suzuki, K. I. \& Nakase, T. (1999). A new rapid method of glycolate test by diethyl ether extraction, which is applicable to a small amount of bacterial cells of less than one milligram. J Gen Appl Microbiol 45, 49-56.

Versalovic, J., Schneider, M., de Bruijn, F. J. \& Lupski, J. R. (1994). Genomic fingerprinting of bacteria using repetitive sequence-based polymerase chain reaction. Methods Mol Cell Biol 5, 25-40.

Wayne, L. G., Brenner, D. J., Colwell, R. R., Grimont, P. A. D., Kandler, O., Krichevsky, M. I., Moore, L. H., Moore, W. E. C., Murray, R. G. E. \& other authors (1987). International Committee on Systematic Bacteriology. Report of the ad hoc committee on reconciliation of approaches to bacterial systematics. Int J Syst Bacteriol 37, 463-464. 
Wink, J. M., Kroppenstedt, R. M., Ganguli, B. N., Nadkarni, S. R., Schumann, P., Seibert, G. \& Stackebrandt, E. (2003). Three new antibiotic producing species of the genus Amycolatopsis, Amycolatopsis balhimycina sp. nov., A. tolypomycina sp. nov., A. vancoresmycina sp. nov., and description of Amycolatopsis keratiniphila subsp. keratiniphila subsp. nov. and A. keratiniphila subsp. nogabecina subsp. nov. Syst Appl Microbiol 26, 38-46.

Wink, J., Gandhi, J., Kroppenstedt, R. M., Seibert, G., Sträubler, B., Schumann, P. \& Stackebrandt, E. (2004). Amycolatopsis decaplanina sp. nov., a novel member of the genus with unusual morphology. Int $J$ Syst Evol Microbiol 54, 235-239.

Yassin, A. F., Schaal, K.-P., Brzezinka, H., Goodfellow, M. \& Pulverer, G. (1991). Menaquinone patterns of Amycolatopsis species. Zentralbl Bakteriol 274, 465-470.

Zucchi, T. D., Tan, G. Y. A. \& Goodfellow, M. (2012). Amycolatopsis thermophila sp. nov. and Amycolatopsis viridis sp. nov., thermophilic actinomycetes isolated from arid soil. Int J Syst Evol Microbiol 62, $168-172$. 